\title{
Quality of life related to residual snoring after adenotonsillectomy: a pilot study
}

Rita Catia Brás Bariani**

Thais Moura Guimaraes ${ }^{2}$

Wilana Moura ${ }^{3}$

Mario Cappellette Junior ${ }^{1}$

Sergio Tufik ${ }^{2}$

Gustavo A. Moreira ${ }^{2}$

Reginaldo Raimundo Fujita ${ }^{1}$

${ }^{1}$ Universidade Federal de São Paulo, Department of Otorhinolaryngology and Head and Neck Surgery - São Paulo - SP - Brazil.

${ }^{2}$ Universidade Federal de São Paulo, Departamento de Psicobiologia - São Paulo - SP - Brazil.

${ }^{3}$ Faculdade de Odontologia de Bauru, Departamento de Ortodontia - São Paulo - SP - Brazil.
*Corresponding author: Rita Catia Bariani

E-mail: ritabariani@hotmail.com

Received: September 2, 2020;

Accepted: February 1, 2021.

DOI: $10.5935 / 1984-0063.20200093$

\begin{abstract}
Introduction: Few studies have addressed long-term quality of life related to residual snoring after adenotonsillectomy. The aim of this study was to compare scores from the OSA-18 questionnaire between children with residual snoring and non-snoring children two or more years after adenotonsillectomy. Material and Methods: The sample comprised 25 children divided into two groups, a group of 14 snoring children, and a control group of 11 non-snoring children. The OSA-18 questionnaire was applied to the volunteers. In the control group, it was completed by the caregivers of the children, while in individuals with residual snoring it was completed by the caregivers of children in the presence of a doctor or dentist. A statistical comparison was made using a generalized linear model. Results: The snorer group had a higher total OSA-18 score, and a higher score in all five domains compared to the control group. Conclusion: Children with residual snoring two or more years after adenotonsillectomy may have a worse quality of life compared to the control group.
\end{abstract}

Keywords: Sleep Apnea; Obstructive; Snoring; Indicators of Quality of Life; Tonsillectomy. 


\section{INTRODUCTION}

In childhood, sleep-disordered breathing is associated with a myriad of health problems that reinforce the need for early diagnosis and treatment ${ }^{1}$. The prevalence of obstructive sleep apnea (OSA) in children over 3 years of age varies from $7.2 \%$ to $34.2 \%{ }^{2}$, whereas habitual snoring has a prevalence of $5-35 \%{ }^{3}$.

The most common otorhinolaryngological condition in children with OSA is adenotonsillar hypertrophy, with or without allergic rhinitis, and mouth breathing ${ }^{4}$. The goldstandard treatment for OSA in children is adenotonsillectomy, which normalizes polysomnography and improves quality of $\operatorname{life}^{5-7}$. Some patients still require additional treatment using alternative methods such as corticosteroids, rapid maxillary expansion $^{8}$, myofunctional therapy', behavioral measures for weight loss and $\operatorname{diet}^{10}$, or CPAP ${ }^{11}$. The orthodontic treatment for correction of maxillomandibular abnormalities or mandibular retrusion has been shown to improve OSA ${ }^{12}$. In addition, the sequelae of chronic oral breathing need to be corrected by the global treatment, which should involve a multidisciplinary team of sleep medicine that include: otorhinolaryngologist, speech and/or orthodontic therapy to restore normal breathing and craniofacial growth patterns ${ }^{13}$.

Studies have demonstrated that adenotonsillectomy can have a positive effect on a number of different aspects of the condition, such as improving behavior, cognition, and quality of life of children with adenotonsillar hyperplasia ${ }^{14-17}$. However, most studies assess any improvements immediately, or for only a few months, after surgery. Few studies have analyzed these results over the long-term, with periods equal to, or greater than one year. Lima Junior et al. $(2008)^{18}$ reported that a positive impact on quality of life was maintained for about 15 months after surgery. Significant improvement was observed in sleep-related QOL and behavioral problems in children with OSA during long-term follow-up after adenotonsillectomy ${ }^{19}$.

Another interesting finding was that, while short-term and long-term benefits of surgery were achieved, the score for the domain of physical symptoms was higher in the long-term, implying that caregivers perceive some recurrence of physical symptoms after surgery in their children despite long-term improvement in quality of life ${ }^{20}$.

Based on these findings, clinicians should note the potential for long-term changes in certain domains of quality of life; therefore, children with OSA require both short-term and long- term quality of life follow up after surgery. OSA can persist after adenotonsillectomy in $21 \%$ to $75 \%{ }^{21,22}$. The possible factors that influence the failure of the surgery are patient comorbidities such as obesity, craniofacial anomalies, and nasal obstruction ${ }^{21,23}$.

Patients with residual OSA continue to have a low quality of $\operatorname{life}^{24}$. However, few studies have addressed quality of life in patients with only residual snoring after late adenotonsillectomy surgery. SDB (respiratory sleep disorder) is widely studied due to its high prevalence, but it is not often considered in routine childcare visits ${ }^{25,26}$.

Failure to treat children with OSA can lead to a range of impairments that include behavioral problems ${ }^{27,28}$, increased cardiovascular dysfunction ${ }^{29,30}$, and impaired growth and development ${ }^{30}$. One of the complications of OSA in children is the increased prevalence of neurodevelopmental ${ }^{31,32}$. Children with primary snoring are also at risk of developmental disorders and behavioral disorders ${ }^{32,33}$. Persistent snoring and nocturnal enuresis can affect interpersonal relationships and quality of $\operatorname{life}^{34}$. Therefore, the objective of this study is to evaluate the quality of life by the OSA-18 of children with residual snoring 2 years after adenotonsillectomy surgery and a control group without snoring complaints.

\section{MATERIAL AND METHODS}

In this pilot study, the sample comprised 2 groups, one with snoring children at least 2 years after adenotonsillectomy surgery, and a control group without snoring. Four hundred caregivers of patients who had undergone adenotonsillectomy at Hospital São Paulo were interviewed. Children who continued to have snoring symptoms were recruited into the study. The inclusion criteria were children, boys and girls, aged between 5 and 12 years old. The exclusion criteria were children with cardiac, pulmonary, neuromuscular diseases, and chromosomal syndromes. This study was approved by the research ethics committee of the Universidade Federal de São Paulo, number $0698011806 / 2017$. The clinical trial registration number is RBR- 463byn.

\section{Snoring group}

The group comprised 14 snoring children who were selected from patients, attending the Outpatient Clinic of the Pediatric Otorhinolaryngology Department at the Escola Paulista de Medicina, Universidade Federal de São Paulo, who had previously undergone adenotonsillectomy (a minimum period of 2 years) and had a severe snoring complaint on most nights, or every night, over the previous four weeks (questionnaire OSA-18). All children in this group underwent an otorhinolaryngological clinical examination, nasofibroscopy, and polysomnography.

\section{Control group}

The control group were selected from the Escola Paulistinha de Educação, an elementary school of education for Unifesp workers, and comprised 11 children selected at random who did not snore, according to the results of the OSA-18 questionnaire.

\section{Procedures}

\section{OSA-18 Questionnaire}

The OSA-18 is a questionnaire (Supplementary Table) designed to be used with children, validated in Portuguese $e^{34}$, that assesses the quality of life in children with apnea ${ }^{35}$. 
OSA-18 consists of 18 questions divided into 5 domains: sleep disorder, physical symptoms, emotional symptoms, daytime function and caregiver concerns, each item has a score of 7 points ( 1 - "never" to 7 - "always") ${ }^{34-36}$. Values less than 60 have a mild impact on quality of life, 60 to 80 have a moderate impact on quality of life, and above 80 is considered a serious impact on quality of life.

In healthy volunteers, the caregivers completed the questionnaire, while in individuals with residual snoring it was carried out by the children's caregivers, in the presence of an otorhinolaryngologist or orthodontist.

Polysomnography

Only patients with residual snoring underwent an overnight polysomnography exam. The polysomnography considered the following values: children with an obstructive apnea/hypopnea index $(\mathrm{OAHI})>2$ /hour, or an obstructive apnea index $(\mathrm{OAI})>1 /$ hour, were considered abnormal, in addition to percutaneous oxyhemoglobin saturation $\left(\mathrm{SpO}_{2}\right)$ $<92 \%{ }^{37}$ (Table 1).

Table 1. Snorer sample: polysomnography characteristics.

\begin{tabular}{lc}
\hline Variables & Snorer \\
\hline Sleep efficiency & $80.7 \% \pm 13.3$ \\
Sleep latency & $45.1 \% \pm 40.4$ \\
Arousal index & $7.8 \% \pm 3.7$ \\
AHI & $1.4\left(\mathrm{n}^{\circ} / \mathrm{h}\right) \pm 1.3$ \\
Obstructive AHI & $1.1\left(\mathrm{n}^{\circ} / \mathrm{h}\right) \pm 1.2$ \\
Central AHI & $0.3\left(\mathrm{n}^{\circ} / \mathrm{h}\right) \pm 0.4$ \\
RDI & $1.5\left(\mathrm{n}^{\circ} / \mathrm{h}\right) \pm 1.4$ \\
Baseline $\mathrm{SpO}_{2}$ & $96.6 \% \pm 1.1$ \\
Mean $\mathrm{SpO}_{2}$ & $95.7 \% \pm 1.4$ \\
Minimum $\mathrm{SpO}_{2}$ & $91 \% \pm 3.3$ \\
\hline
\end{tabular}

Notes: AHI: Apnea-hypopnea index; RDI: Respiratory disturbance index; SpO2: Oxygen saturation.

Statistical analysis

Shapiro-Wilk tests were used to evaluate the distribution of the variables. Descriptive data were presented as means and standard deviations or absolute frequency, and data were analyzed using a generalized linear model (GzLM) test. For the categorical variables, a GzLM with binary logistic distribution was used, and gamma distribution was used for continuous variables. A $p$ - value of $\leq 0.05$ was considered significant.

\section{RESULTS}

The sample comprised 25 children, 14 snorers after adenotonsillectomy, and 11 controls. The evaluation of the OSA-18 questionnaire was controlled by age values. There was no difference between groups in respect of the anthropometric absolute and z score, and sex (Table 2). However, the snorers were older than the control group. All domains of quality of life in the OSA-18 were worse in the snorer group than in the control group. As a result, the snorer group had the highest total OSA-18 score, as well as the highest score in all 5 domains compared to control. The overall average score for OSA-18 was 82.5 (severe impact), which was statistically significant compared to the control group $(p>0.05)$. In the descriptive assessment of polysomnography, snorers had an average obstructive apnea/hypopnea index of $1.1 \pm 1.2$ and a minimum saturation of $91 \% \pm 3.3$ and a $95.7 \% \pm 1.4$ (Table 3).

Table 2. Total sample characteristics.

\begin{tabular}{lccc}
\hline Variables & Control & Snorers & $\boldsymbol{p}$ \\
\hline Males, n(\%) & $11(79)$ & $14(56)$ & 0.30 \\
Age, mean(SD) & $7.9 \pm 1.2$ & $9.7 \pm 1.8$ & $<0.01$ \\
BMI z-score, mean (SD) & $2.0 \pm 2.5$ & $1.7 \pm 2.8$ & 0.71 \\
\hline
\end{tabular}

Notes: GzLM test; SD: Standard deviation.

Table 3. Total sample: OSA-18 characteristics.

\begin{tabular}{lccc}
\hline Variables & Control & Snorers & $\boldsymbol{p}$ \\
\hline Sleep disturbance & $5 \pm 1.6$ & $19.6 \pm 5.6$ & $<0.01$ \\
Physical symptoms & $8.4 \pm 6.8$ & $18.2 \pm 5.1$ & $<0.01$ \\
Emotional symptoms & $4.9 \pm 2.8$ & $13.4 \pm 4.5$ & $<0.01$ \\
Daytime function & $6 \pm 3.7$ & $12.8 \pm 6.0$ & $<0.01$ \\
Caregiver concerns & $6.3 \pm 3.2$ & $19.2 \pm 7.9$ & $<0.01$ \\
Total & $30.5 \pm 12.4$ & $83.1 \pm 20.7$ & $<0.01$ \\
\hline
\end{tabular}

Note: GLZM test, adjusted for age.

\section{DISCUSSION}

All domains of quality of life evaluated by the OSA18 were worse in the snoring group after adenotonsillectomy compared to healthy individuals.

The highest mean scores of the OSA-18 were observed for the domains "sleep disturbance", followed by "caregiver concerns", and "physical symptoms", which involve questions about the most common aspects of apnea, namely snoring, choking, restless sleep, mouth breathing, upper airway infection, difficult feeding, concern of the parents about the child's health. Lee et al. (2015) $)^{20}$ in their study also scored for the domain of physical symptoms was higher in the long run, implying that caregivers perceive some recurrence of physical symptoms after surgery in their children despite the long-term improvement in quality of life. However, Mitchell et al. (2004) ${ }^{38}$ found results similar to our study also in the domains sleep disorders and physical suffering were significantly lower $(p .005)$ in the shortterm than in the long-term.

This study is relevant, because the impact of residual snoring on the quality of life of children who had undergone adenotonsillectomy 2 or more years previously is of great importance. It was observed that in all domains of quality of life evaluated by the OSA-18 were worse in the snoring group after adenotonsillectomy compared to healthy individuals. These results should alert all professionals who deal with patients with similar profiles to check for the presence of snoring in the long-term postoperative period and to seek treatment alternatives. 
The data found in this study can contribute to the reevaluation and retreatment of these children to improve their quality of life. It is interesting to note that there are many studies that show that children with primary snoring present changes in their quality of life and more behavioral problems when compared to the control groups ${ }^{39-43}$. However, our study uses a sample of children at least 2 years after the adenotonsillectomy who have signs and symptoms of OSA. Also a systematic review demonstrated the effectiveness of adenotonsillectomy in improving the quality of life of pediatric patients with OSA ${ }^{44}$. All studies involving shortterm follow-up ( $\leq 6$ months) have shown improvements in quality of life scores after adenotonsillectomy compared to preoperative values and studies involving long-term follow-up ( $>6$ months) have shown mixed results. We must consider the low educational level and socioeconomic level of parents or guardians and their difficulty in accessing specialized services of the Brazilian health system (SUS). Children who continued to have snoring symptoms were recruited into the study.

Residual snoring should be thoroughly investigated in clinical practice, especially after adenotonsillectomy, as quality of life may be compromised in these children.

Quality of life has been increasingly seen as an important health outcome. OSA-18 is an easy and fast test, with high reliability and consistency, to assess the subjective aspects of quality of life $\mathrm{f}^{7}$. This questionnaire, when combined with other clinical and objective parameters, allows professionals to better assess the impact of OSA on children and their family life, and to select the best type of treatment ${ }^{24}$. Being a subjective tool, it should be used as an adjunct to clinical examination to improve the diagnosis of pediatric OSA and not a replacement for pediatric polysomnography?

The presence of nasal disuse and breathing through the mouth are abnormal functions that cause developmental and functional changes that are associated with the development of DRS. The impact of mouth breathing promotes changes in craniofacial growth patterns and how these changes lead to impaired developmental functions and the consequent persistence of DRS. Understanding the dynamics that lead to the development of DRS and recognizing the factors that affect craniofacial growth and the resulting functional impairments, allows for an adequate multidisciplinary treatment planning for sleep apnea in childhood. The increase in lymphoid tissue may actually be a consequence and not a cause of these initial dysfunctions ${ }^{45}$.

This study is unique for investigating long-term $(>2$ years) quality life of children submitted to adenotonsillectomy and the comparison with a control group. However, is has some limitations, including small sample size, limited spectrum of the condition, and a non-surgical control group.

As the effect size of the difference between groups were huge, the small sample size did not affect the final results.

Were choose to have a healthy control group, instead of a post-surgical, in order to have a purer comparison. Yet, a study comparing children post-adenotonsillectomy with and without residual snoring still need to be done. Confirmatory results are essential, and the repetition of studies by other researchers, replicating the conditions described, will produce the evidence for the advancement of science.

\section{CONCLUSION}

The data suggest that snoring patients two or more years after adenotonsillectomy surgery have worse quality of life compared to the control group in long-term follow-up.

\section{REFERENCES}

1. Schechter MS. Technical report: diagnosis and management of childhood obstructive sleep apnea syndrome. Pediatrics. 2002 Apr;109(4):e69.

2. Izu SC, Itamoto CH, Pradella-Hallinan M, Pizarro GU, Tufik S, Pignatari S, et al. Obstructive sleep apnea syndrome (OSAS) in mouth breathing children. Braz J Otorhinolaryngol. 2010 Oct;76(5):552-6. DOI: https://doi.org/10.1590/S1808-86942010000500003

3. Petry C, Pereira MU, Pitrez PM, Jones MH, Stein RT. The prevalence of symptoms of sleep- disordered breathing in Brazilian schoolchildren. J Pediatr (Rio J). 2008 Apr;84(2):123-9. DOI: https://doi.org/10.1590/ S0021-75572008000200006

4. Chervin RD, Ruzicka DL, Hoban TF, Fetterolf JL, Garetz SL, Guire KE, et al. Esophageal pressures, polysomnography, and neurobehavioral outcomes of adenotonsillectomy in children. Chest. 2012 Jul;142(1):101-10. DOI: https://doi.org/10.1378/chest.11-2456

5. Guilleminault C, Huang YS, Glamann C, Li K, Chan A. Adenotonsillectomy and obstructive sleep apnea in children: a prospective survey. Otolaryngol Head Neck Surg. 2007 Feb;136(2):16975. DOI: https://doi.org/10.1016/j.otohns.2006.09.021

6. Tauman R, Gulliver TE, Krishna J, Montgomery-Downs HE, O’Brien LM, Ivanenko A, et al. Persistence of obstructive sleep apnea syndrome in children after adenotonsillectomy. J Pediatr. 2006 Dec;149(6):803-8. DOI: https://doi.org/10.1016/j.jpeds.2006.08.067

7. Sistla SK, Lahane V. OSA 18 questionnaire: tool to evaluate quality of life and efficacy of treatment modalities in pediatric sleep disordered breathing due to adenotonsillar hypertrophy. Indian J Otolaryngol Head Neck Surg. 2019 Nov;71. DOI: https://doi.org/10.1007/s12070-019-01757-0

8. Lagravere MO, Major PW, Flores-Mir C. Long-term dental arch changes after rapid maxillary expansion treatment: a systematic review. Angle Orthod. 2005 Mar;75(2):155- 61.

9. Wu LM, Wu XF, Yu ZM, Liu Y. Systematic review on orofacial myofunctional therapy to treat obstructive sleep apnea-hypopnea syndrome. Lin Chung Er Bi Yan Hou Tou Jing Wai Ke Za Zhi. 2017 Nov;31(22):1774-7.

10. Friedman M, Wilson M, Lin HC, Chang HW. Updated systematic review of tonsillectomy and adenoidectomy for treatment of pediatric obstructive sleep apnea/hypopnea syndrome. Otolaryngol Head Neck Surg. 2009 Jun;140(6):800-8. DOI: https://doi.org/10.1016/j.otohns.2009.01.043

11. Marcus CL, Brooks LJ, Draper KA, Gozal D, Halbower AC, Jones J, et al. Diagnosis and management of childhood obstructive sleep apnea syndrome. Pediatrics. 2012 Sep;130(3):e714-55. DOI: https://doi. org/10.1542/peds.2012-1672

12. Huynh NT, Desplats E, Almeida FR. Orthodontics treatments for managing obstructive sleep apnea syndrome in children: a systematic review and meta-analysis. Sleep Med Rev. 2016 Feb;25:84-94. DOI: https://doi.org/10.1016/j.smrv.2015.02.002

13. Nishikawa H, Pearman K, Dover S. Multidisciplinary management of children with craniofacial syndromes with particular reference to the airway. Int J Pediatr Otorhinolaryngol. 2003 Dec;67(Suppl 1):S91-3. DOI: https://doi.org/10.1016/j.ijporl.2003.08.037

14. Serres LM, Derkay C, Astley S, Deyo RA, Rosenfeld RM, Gates GA Measuring quality of life in children with obstructive sleep disorders. Arch Otolaryngol Head Neck Surg, 2000;126(12):1423-9. DOI: https://doi.org/10.1001/archotol.126.12.1423

15. Serres LM, Derkay C, Sie K, Biavati M, Jones J, Tunkel D, et al. Impact of adenotonsillectomy on quality of life in children with obstructive sleep disorders. Arch Otolaryngol Head Neck Surg. 2002;128(5):48996. DOI: https://doi.org/10.1001/archotol.128.5.489

16. Nascimento GMS, Salgado DC, Maia MS, Lambert EE, Pio MRB, Tiago RSL. Impacto do tratamento cirúrgico na qualidade de vida de crianças com hiperplasia de tonsilas. Acta ORL. 2007;25:119-23.

17. Van Staaji BK, Van Den Akker EH, Rovers MM, Hordijk GJ, Hoes AW, Schilder AG. Effectiveness of adenotonsillectomy in children with mild symptoms of throat infections or adenotonsillar hypertrophy: open, randomised controlled trial. Clin Otolaryngol. 2005 Mar;30(1):60-3. DOI: https://doi.org/10.1111/j.1365-2273.2005.00980.x 
18. Lima Júnior JM, Silva VC, Freitas MR. Long term results in the life quality of children with obstructive sleep disorders submitted to adenoidectomy/ adenotonsillectomy. Braz J Otorhinolaryngol. 2008 Oct;74(5):718-24. DOI: https://doi.org/10.1590/S0034-72992008000500013

19. Song IS, Hong SN, Joo JW, Han MS, Hwang SJ, Seo MY, et al. Longterm results of sleep-related quality-of-life and behavioral problems after adenotonsillectomy. Laryngoscope. 2020 Feb;130(2):546-50. DOI: https://doi.org/10.1002/lary.27951

20. Lee CH, Kang KT, Weng WC, Lee PL, Hsu WC. Quality of life after adenotonsillectomy in children with obstructive sleep apnea: shortterm and long-term results. Int J Pediatr

21. Otorhinolaryngol. 2015 Feb;79(2):210-5. DOI: https://doi. org/10.1016/j.ijporl.2014.12.011

22. Imanguli M, Ulualp SO. Risk factors for residual obstructive sleep apnea after adenotonsillectomy in children. Laryngoscope. 2016;126(11):26249. DOI: https://doi.org/10.1002/lary.25979

23. Pomerantz J. Management of persistent obstructive sleep apnea after adenotonsillectomy. Pediatr Ann. 2016;45(5):e180-3. DOI: https://doi. org/10.3928/00904481-20160329-01

24. Tauman R, Gulliver TE, Krishna J, Montgomery-Downs HE, O’Brien LM, Ivanenko A, et al. Persistence of obstructive sleep apnea syndrome in children after adenotonsillectomy. 2006 Dec;149(6):803-8. DOI: https://doi.org/10.1016/j.jpeds.2006.08.067

25. Silva VC, Leite AJM. Quality of life in children with sleep-disordered breathing: evaluation by OSA-18. Braz J Otorhinolaryngol. 2006 Dec;72(6):747-56. DOI: https://doi.org/10.1590/S0034-72992006000600005

26. Ali N, Pitson D, Stradling J. Snoring, sleep disturbance, and behaviour in 4-5 year olds. Arch Dis Child. 1993;68(3):360-6. DOI: https://doi. org/10.1136/adc.68.3.360

27. Nieminen P, Tolonen U, Löppönen H. Snoring and obstructive sleep apnea in children: a 6month follow-up study. Arch Otoloryngol Head Neck Surg. 2000;126(4):481-6.

28. Bruni O. The importance of sleep for children's well being. Sleep Med. 2010 Aug;11(7):599-600. DOI: https://doi.org/10.1016/j.sleep.2010.04.002

29. O’Brien LM, Mervis CB, Holbrook CR, Bruner JL, Klaus CJ, Rutherford J, et al. Neurobehavioral implications of habitual snoring in children. Pediatrics. 2004 Jul;114(1):44-9. DOI: https://doi.org/10.1542/peds.114.1.44

30. American Academy of Sleep Medicine (AASM). International classification of sleep disorders. 3rd ed. Darien, IL: AASM; 2014.

31. Gozal D, Pope Junior DW. Snoring during early childhood and academic performance at ages thirteen to fourteen years. Pediatrics. 2001 May:107(6):1394-9. DOI: https://doi.org/10.1542/peds.107.6.1394

32. O’Brien LM, Holbrook CR, Mervis CB, Klaus CJ, Bruner JL, Raffield TJ, et al. Sleep and neurobehavioral characteristics of 5- to 7-yearold children with parentally reported symptoms of attention-deficit/ hyperactivity disorder. Pediatrics. 2003 Mar;111(3):554-63. DOI: https://doi.org/10.1542/peds.111.3.554

33. Tsara V, Amfilochiou A, Papagrigorakis JM, Georgopoulos D, Liolios E, Kadiths A, et al. Guidelines for diagnosing and treating sleep related breathing disorders in adults and children (Part 3: obstructive sleep apnea in children, diagnosis and treatment). Hippokratia. 2010 Jan;14(1):57-62.
34. Uema SFH, Pignatari SSN, Fujita RR, Moreira GA, Pradella-Hallinan M, Weckx L. Assessment of cognitive learning function in children with obstructive sleep breathing disorders. Braz J Otorhinolaryngol. 2007 May/Jun;73(3):315-20. DOI: https://doi.org/10.1016/s18088694(15)30074-4

35. Fernandes FMVS, Teles RCVV. Questionário da síndrome da apneia obstrutiva na criança- 18: versão portuguesa. Braz J Otorhinolaryngol. 2013 Nov/Dec;79(6):720-6. DOI: http://dx.doi.org/10.5935/18088694.20130132

36. Franco Junior RA, Rosenfeld RM, Rao M. First place--resident clinical science award 1999. Quality of life for children with obstructive sleep apnea. Otolaryngol Head Neck Surg. 2000 Jul;123(1):9-16. DOI: https://doi.org/10.1067/mhn.2000.105254

37. Baldassari CM, Mitchell RB, Schubert C, Rudnick EF. Pediatric obstructive sleep apnea and quality of life: a meta-analysis. Otolaryngol Head Neck Surg. 2008 Mar;138(3):265-73. DOI: https://doi org/10.1016/j.otohns.2007.11.003

38. Marcus CL, Moore RH, Rosen CL, Giordani B, Garetz SL, Taylor G, et al. A randomized trial of adenotonsillectomy for childhood sleep apnea. N Engl J Med. 2013 Jun;368(25):2366-76. DOI: https://doi. org/10.1056/NEJMoa1215881

39. Mitchell RB, Kelly J, Call E, Yao N. Long-term changes in quality of life after surgery for pediatric obstructive sleep apnea. Arch Otolaryngol Head Neck Surg. 2004 Apr;130(4):409-12. DOI: https:// doi.org/10.1001/archotol.130.4.409

40. Crabtree VM, Varni JW, Gozal D. Health-related quality of life and depressive symptoms in children with suspected sleep-disordered breathing. Sleep. 2004 Sep;27(6):1131-8. DOI: https://doi. org/10.1093/sleep/27.6.1131

41. Goldstein NA, Fatima M, Campbell TF, Rosenfeld RM. Child behavior and quality of life before and after tonsillectomy and adenoidectomy. Arch Otolaryngol Head Neck Surg. 2002 Jul;128(7):770-5. DOI https://doi.org/10.1001/archotol.128.7.770

42. Montgomery-Downs HE, Crabtree VM, Gozal D. Cognition, sleep and respiration in at-risk children treated for obstructive sleep apnoea. Eur Respir J. 2005;25(2):336-42. DOI: https://doi.org/10.1183/09031936. 05.00082904

43. Blunden S, Lushington K, Kennedy D, Martin J, Dawson D. Behavior and neurocognitive performance in children aged 5-10 years who snore compared to controls. J Clin Exp Neuropsychol. 2000;22(5):554-68. DOI: https://doi.org/10.1076/1380-3395(200010)22:5;1-9;FT554

44. Honaker SM, Street A, Daftary AS, Downs SM. The use of computer decision support for pediatric obstructive sleep apnea detection in primary care. J Clin Sleep Med. 2019 Mar;15(3):453-62. DOI: https:// doi.org $/ 10.5664 /$ jcsm. 7674

45. Todd CA, Bareiss AK, McCoul ED, Rodriguez KH. Adenotonsillectomy for obstructive sleep apnea and quality of life: systematic review and meta-analysis. Otolaryngol Head Neck Surg. 2017 Nov;157(5):767-73. DOI: https://doi.org/10.1177/0194599817717480

46. Guilleminault C, Akhtar F. Pediatric sleep-disordered breathing: new evidence on its development. Sleep Med Rev. 2015 Dec;24:46-56. DOI: https://doi.org/10.1016/j.smrv.2014.11.008 
OSA-18 for children with OSAS - English version.

OSAS Quality of Life Survey (OSA-18) Date: _ /_ /_

Name:

For each question below, please circle the number that best describes how often each symptom or problem has occurred during the past 4 weeks.

Please circle only one number per question. Thank you.

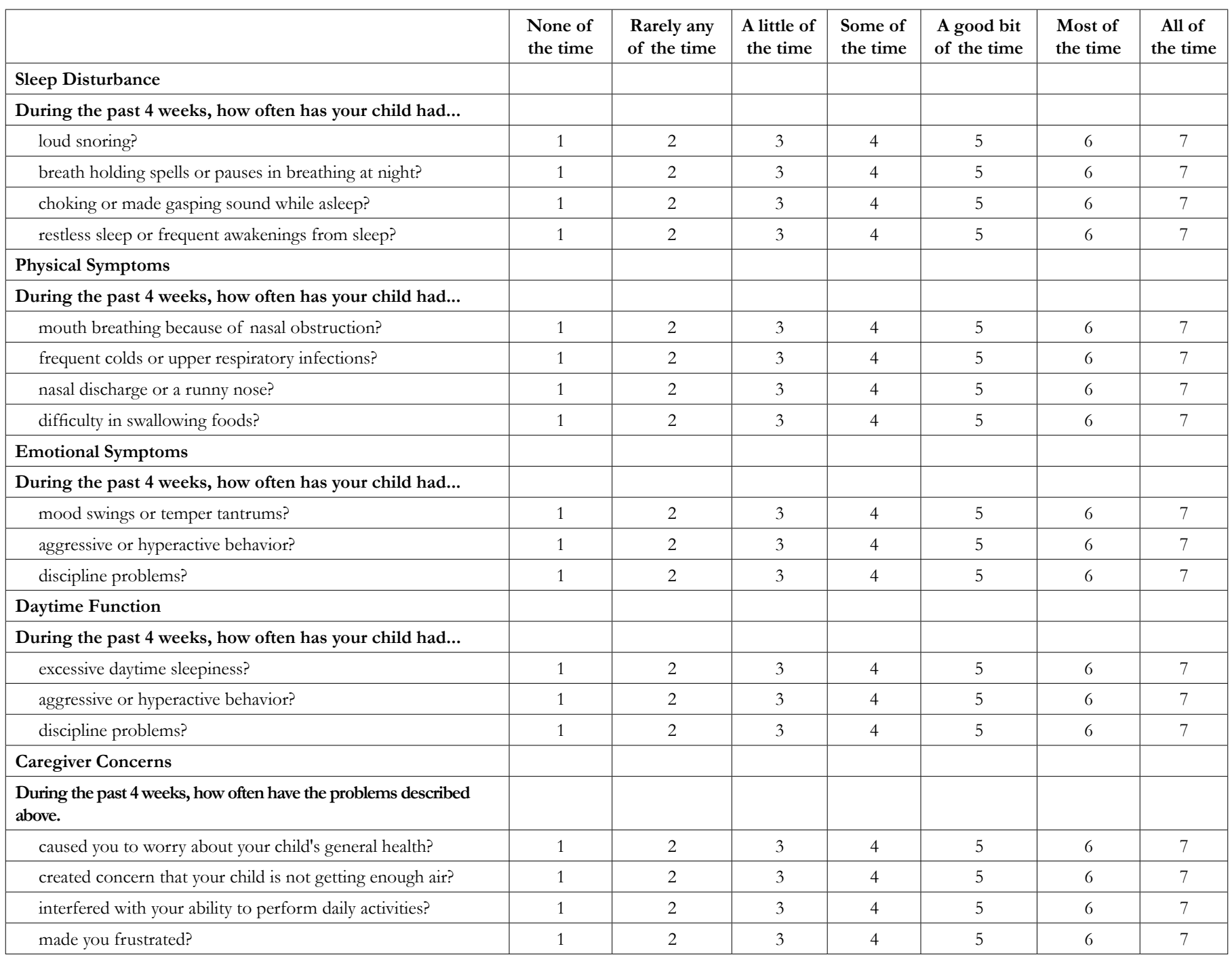

\section{Portuguese version of OSA-18 (OSA-18-pv)}

OSA-18 Versão Portuguesa (OSA-18-pv) Data:_ / _ / _

Nome:

Em cada uma das questões seguintes, faça por favor um círculo à volta do número que melhor descreve a frequência

de cada sintoma ou problema nas últimas 4 semanas. Assinala apenas um número por questão. Obrigado.

\begin{tabular}{|c|c|c|c|c|c|c|c|}
\hline & Nunca & $\begin{array}{l}\text { Quase } \\
\text { Nunca }\end{array}$ & $\begin{array}{c}\text { Poucas } \\
\text { Vezes }\end{array}$ & $\begin{array}{c}\text { Algumas } \\
\text { Vezes }\end{array}$ & $\begin{array}{c}\text { Bastantes } \\
\text { vezes }\end{array}$ & $\begin{array}{l}\text { Quase } \\
\text { Sempre }\end{array}$ & Sempre \\
\hline \multicolumn{8}{|l|}{ Distúrbio do Sono } \\
\hline ressonar alto? & 1 & 2 & 3 & 4 & 5 & 6 & 7 \\
\hline paragens na respiração durante a noite? & 1 & 2 & 3 & 4 & 5 & 6 & 7 \\
\hline engasgos ou respiração ofegante enquanto dormia? & 1 & 2 & 3 & 4 & 5 & 6 & 7 \\
\hline
\end{tabular}


Continuation.

\begin{tabular}{|c|c|c|c|c|c|c|c|}
\hline \multicolumn{8}{|l|}{ Sintomas Físicos } \\
\hline \multicolumn{8}{|l|}{ Nas últimas 4 semanas, com que frequência o seu filho teve... } \\
\hline respiração bucal por obstrução nasal? & 1 & 2 & 3 & 4 & 5 & 6 & 7 \\
\hline resfriados ou infecções das vias aéreas superiores? & 1 & 2 & 3 & 4 & 5 & 6 & 7 \\
\hline secreção e congestão nasal? & 1 & 2 & 3 & 4 & 5 & 6 & 7 \\
\hline dificuldade em engolir alimentos? & 1 & 2 & 3 & 4 & 5 & 6 & 7 \\
\hline \multicolumn{8}{|l|}{ Problemas emocionais } \\
\hline \multicolumn{8}{|l|}{ Nas últimas 4 semanas, com que frequência o seu filho teve... } \\
\hline alterações do humor ou acessos de raiva? & 1 & 2 & 3 & 4 & 5 & 6 & 7 \\
\hline comportamento agressivo ou hiperactivo? & 1 & 2 & 3 & 4 & 5 & 6 & 7 \\
\hline problemas disciplinares? & 1 & 2 & 3 & 4 & 5 & 6 & 7 \\
\hline \multicolumn{8}{|l|}{ Problemas do quotidiano } \\
\hline \multicolumn{8}{|l|}{ Nas últimas 4 semanas, com que frequência o seu filho teve... } \\
\hline sonolência diurna excessiva? & 1 & 2 & 3 & 4 & 5 & 6 & 7 \\
\hline episódios de falta de atenção ou concentração? & 1 & 2 & 3 & 4 & 5 & 6 & 7 \\
\hline dificuldade ao levantar da cama de manhã? & 1 & 2 & 3 & 4 & 5 & 6 & 7 \\
\hline \multicolumn{8}{|l|}{ Opinião do Informante } \\
\hline \multicolumn{8}{|l|}{$\begin{array}{l}\text { Nas últimas } 4 \text { semanas, com que frequência os problemas } \\
\text { acima descritos... }\end{array}$} \\
\hline causaram preocupação com a sua saúde? & 1 & 2 & 3 & 4 & 5 & 6 & 7 \\
\hline preocuparam-no pelo seu filho não poder respirar ar suficiente? & 1 & 2 & 3 & 4 & 5 & 6 & 7 \\
\hline interferiram com as suas actividades diárias? & 1 & 2 & 3 & 4 & 5 & 6 & 7 \\
\hline deixaram-no frustrado? & 1 & 2 & 3 & 4 & 5 & 6 & 7 \\
\hline
\end{tabular}

